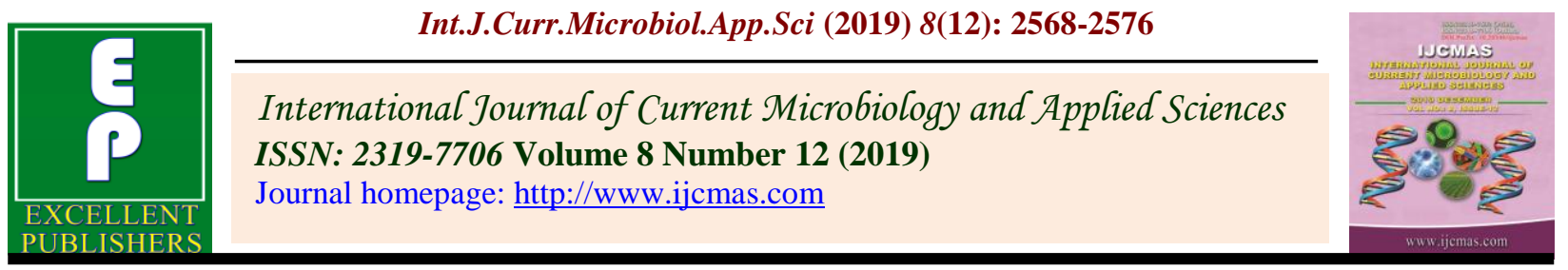

Original Research Article

https://doi.org/10.20546/ijcmas.2019.812.300

\title{
Phenotypic and Genotypic Characterization of Antimicrobial Resistance of Enterobacteriaceae Isolated from Free Range Chicken in Andhra Pradesh
}

\author{
M. Divya ${ }^{1}$, B. Sreedevi ${ }^{1 *}$, R. K. Chaitanya ${ }^{1}$ and Ch. Srilatha ${ }^{2}$ \\ ${ }^{1}$ Department of Veterinary Microbiology, ${ }^{2}$ Department of Veterinary Pathology, College of \\ Veterinary Science, Sri Venkateswara Veterinary University, Tirupati, India \\ *Corresponding author
}

\begin{tabular}{|l|}
\hline Ke y w o r d s \\
$\begin{array}{l}\text { Free range chicken, } \\
\text { Enterobacteriaceae, } \\
\text { Antibiotic } \\
\text { resistance, Tet A } \\
\text { and bla } a_{\mathrm{TEM}} \text { genes }\end{array}$ \\
\hline Article Info \\
\hline $\begin{array}{l}\text { Accepted: } \\
20 \text { November } 2019 \\
\text { Available Online: } \\
\text { 10 December } 2019\end{array}$ \\
\hline
\end{tabular}

A B S T R A C T
Antimicrobial resistance in bacteria from the family Enterobacteriaceae is an important indicator of the emergence of resistant bacterial strains in the gut microbiota. A total of 150 cloacal swabs were collected from free range chickens, 217 Enterobacteriaceae isolates were identified. This study investigated the antimicrobial susceptibility and resistance of commensal Enterobacteriaceae from free-range chickens to 14 antimicrobial agents using the disc diffusion method. Hundred per cent phenotypic resistance of the isolates was noticed against bacitracin, colistin, nitrofurazone, furazolidone, virginomycin, vancomycin and tylosine. Moderate resistance (70-25\%) of isolates was noticed against doxycycline $\mathrm{HCl}$, ampicillin, cefotaxime, ciprofloxacin and chloramphenicol. Least resistance $(<25 \%)$ of isolates was recorded against enrofloxacin and gentamicin. The genotypic resistance of the Enterobacteriaceae to tetracycline was detected by targeting tet- $A$ gene. About $90.9 \%$ of phenotypic resistant samples were found to harbour tet- $A$ gene. Resistance to ampicillin was detected by targeting $b l a_{\text {TEM }}$ gene and $90.55 \%$ of phenotypic resistant samples against ampicillin were found to have $b l a_{\text {TEM }}$ gene.

\section{Introduction}

Backyard poultry keeping indeed constitutes an integral part of many households in rural areas. It plays an important role in providing additional income and high quality protein with negligible production input from the farmer. Free-range chickens reared under an extensive management system scavenge for food and receive little or no antimicrobials as feed additives. They are also highly resistant to different infectious diseases. Because of this reason and also of the rich taste and flavour of desi chicken there is preferential consumption of desi chicken meat and eggs.

In commercial poultry antimicrobials are used as growth promoters and also used for the 
treatment of infections caused by common poultry pathogens such as Salmonella, E.coli, Campylobacter and Clostridium. There is emergence of multi drug resistant bacteria which are excreted in the faeces and gain entry in to the poultry litter. The poultry litter is usually used as fertilizer in agricultural fields, there by multi drug resistant bacteria can enter in to the environment. From the environment humans and other birds may acquire these resistant bacteria. Scavenging free-range chickens may also be asymptomatic carriers and shedders of resistant bacteria in their faces, thereby contaminating the environment. These pathogens can thus be transmitted to other animal hosts and humans where they produce disease.

\section{Materials and Methods}

\section{Sample collection}

A total of 150 cloacal swabs were collected from different villages in and around Tirupati, A.P. which include Chittoor, Venkatagiri, Tirupati, Nagalapuram, Pallam, Vampalli, B.Kandriga and Kalahasti.

\section{Isolation and identification of bacteria}

Cloacal swab samples from broth cultures were incubated aerobically at $37^{\circ} \mathrm{C}$ for 24 hours and loop full of enriched broth culture was streaked onto nutrient agar plates. Isolated single colonies were identified and further streaked onto MacConkey agar. Characteristic lactose-fermenting and non-lactose fermenting colonies on MacConkey agar were picked up and further streaked onto EMB and XLD agar plates, respectively.

Members of Enterobacteriaceae were presumptively identified based on catalase (positive) and oxidase (negative) reactions. Lactose fermenting pink colonies on MacConkey agar and green metallic sheen colonies on EMB agar were presumptively identified as E.coli and were confirmed by IMVIC (++--) and TSI agar ( $\left./ \mathrm{Y} / \mathrm{H}_{2} \mathrm{~S}-\mathrm{ve}\right)$ tests. Lactose fermenting mucoid colonies on MacConkey agar and dark centered pale mucoid colonies on EMB agar were presumptively identified as Klebsiella spp. and were further confirmed by capsular staining, motility (negative) and IMVIC (--++) tests.

Lactose non-fermenting pale colonies on MacConkey agar, red or opaque colonies on BGA and black centered colonies on XLD agar were presumptively identified as Salmonella spp. and were confirmed by IMVIC (-+-+) and TSI agar $\left(\mathrm{R} / \mathrm{YH}_{2} \mathrm{~S}+\mathrm{ve}\right)$ tests.

\section{Antimicrobial sensitivity test}

All the identified isolates were subjected to antimicrobial sensitivity testing by disc diffusion method on Muller Hinton (MH) Agar (Bauer et al., 1966). Inhibition zone diameters were interpreted according to CLSI (2014) guidelines (M100-S24). MacFarland standard (0.5) equivalent to an approximate cell density of $1.5 \times 10^{8} \mathrm{CFU} / \mathrm{mL}$ was used as reference to adjust turbidity of microbial suspensions. Commonly used antibiotics in commercial poultry farming were selected and ABST was performed.

A total of 14 antibiotic discs were selected in the present study. The discs used include ampicillin, bacitracin, cefotaxime, chloramphenicol, ciprofloxacin, colistin, doxycycline HCL, gentamicin, enrofloxacin, vancomycin, furazolidone, nitrofurazone, virginomycin and tylosine.

\section{DNA extraction}

DNA extraction was carried out by boiling and snap chilling method as described by Rao (2009) with minor modifications. 


\section{PCR}

Resistance to tetracycline was detected by targeting tet- $A$ gene as per the procedure described by Randall et al., (2004). The tet-A gene was amplified by uniplex PCR using specific primers (F: GGTTCACTC GAACGACGTCA and R: CTGTCCG ACAAGTTGCATGA). Resistance to ampicillin was detected by targeting $b l a_{\mathrm{TEM}}$ gene as per the procedure described by Dallenee et al., (2010). bla TEM $_{\text {Tene }}$ was amplified by using specific primers (F:CATTTCCGTGTCGCCCTTATTC and $\mathrm{R}:$ CGTTCATCCATAGTTGCCTGAC) in uniplex PCR.

\section{Results and Discussion}

\section{Isolation and Identification of} Enterobacteriaceae

In this study, a total of 217 isolates with reference to the family Enterobacteriaceae were obtained from the faeces of free-range chickens. A total of $130(59.9 \%)$ were characterized as E. coli, $42(19.35 \%)$ were characterized as Salmonella spp. and 45 $(20.73 \%)$ isolates were characterized as Klebsiella spp. In a study conducted by Ojo et al., (2012) in Nigeria, out of 184 isolates tested, the most prevalent bacteria of free range chicken were reported to be E.coli, Klebsiella spp. and Salmonella spp.

\section{Phenotypic antimicrobial resistance of Enterobacteriaceae}

Overall, Hundred percent phenotypic resistance was noticed against bacitracin, colistin, nitrofurazone, furazolidone, virginomycin, vancomycin and Tylosine. Moderate resistance (70-25\%) was noticed against Doxycycline $\mathrm{HCl}$, ampicillin, cefotaxime, ciprofloxacin and chloramphenicol. Least resistance $(<25 \%)$ was recorded against enrofloxacin and gentamicin (Table 1 and Fig. 1). In a similar study conducted by Odomene and Enwere (2018) from chicken slaughter houses of Nigeria, higher phenotypic resistance levels were reported to chloramphenicol (75.9\%), amoxicillin $(73.4 \%)$, gentamicin $(44.3 \%)$ and ciprofloxacin $(20.3 \%)$.

\section{Antimicrobial resistance of $E$.coli}

All the E.coli isolates were found to be resistant to bacitracin, colistin, furazolidone, nitrofurazone, virginomycin, vancomycin and tylosine. A total of $101(77.69 \%)$ isolates showed resistance to Doxycycline $\mathrm{HCl} .93$ out of 130 (71.53\%), 20 (15.38\%), 25 (19.23\%), $38(29.23 \%)$ and $20(15.30 \%)$ isolates were resistant to ampicillin, cefotaxime, chloramphenicol, ciprofloxacin and enrofloxacin respectively. Lowest resistance of $10.76 \%$ (14 isolates) was observed against gentamicin (Table 2). In a study conducted by Obeng et al., (2012) from Nigeria, two hundred fifty one strains of E.coli were isolated from backyard chicken. 40.6 and $26.7 \%$ isolates were resistant to tetracycline and ampicillin. E.coli isolates from free range chicken of Tanzania showed $75 \%$ resistance to tetracycline followed by $63.63 \%$ resistance to ampicillin. 54, 53 and 29\% resistance was observed against ofloxacin, cotrimoxazole and cefotaxime. The least resistance was observed against chloramphenicol (5\%) and cefoxitin (6\%) (Hamisi et al., 2014).

\section{Antimicrobial resistance of Salmonella}

A total of 42 Salmonella isolates showed resistance to bacitracin, colistin, furazolidone, nitrofurazone, vancomycin, virginomycin and tylosine. For Doxycycline $\mathrm{HCl}, 31$ (73.80\%) isolates showed resistance. $16(38.09 \%), 20$ (47.61\%), 15 (35.71\%), $12(28.57 \%)$ and 10 (23.80\%) isolates were resistant to ampicillin, cefotaxime, ciprofloxacin, chloramphenicol 
and enrofloxacin respectively. Lowest resistance of $16.6 \%$ (7 isolates) was noticed against gentamicin (Table 2). In a similar study conducted by Samanta et al., (2014) antibiotic resistance patterns of Salmonella spp. from backyard poultry showed 100\% resistance against chloramphenicol, ciprofloxacin, gentamicin, levofloxacin, norfloxacin and oxytetracycline. In a study conducted by Ghoddusi et al., 2015 in Northern Iran, 44 Salmonella were isolated from backyard chicken. 100\% resistance was observed against tetracycline and doxycycline followed by chloramphenicol (79\%) and florfenicol (72\%) respectively.

\section{Antimicrobial resistance of Klebsiella}

All the Klebsiella spp. isolates were resistant to bacitracin, colistin, furazolidone, nitrofurazone, vancomycin, virginomycin and tylosine. A total of $22(48.8 \%)$ isolates were resistant to Doxycycline. 18 (40\%), 18 (40\%), 14 (31.1\%), $12(26.6 \%)$ and $12(26.6 \%)$ isolates were resistant to ampicillin, cefotaxime, ciprofloxacin, chloramphenicol and enrofloxacin respectively. For gentamicin eleven (24.4\%) isolates showed resistance (Table 2). In a study conducted by Hyati et al., (2019) from East Java, Klebsiella spp. showed $100 \%$ phenotypic resistance against oxytetracycline, ampicillin and amoxicillin. $90.9,54.5,27.3$ and $18.2 \%$ resistance was observed against colistin, doxycycline Hcl, ciprofloxacin and enrofloxacin respectively.

\section{Genotypic resistance of Enterobacteriaceae}

In the present study genotypic resistance of tetracycline and ampicillin was studied. As on today, 38 tetracycline resistance genes have been identified in various bacterial organisms. Out of which, 23 genes are related to efflux proteins such as tet $A$, tet $B$ etc. The efflux genes are the most commonly reported genes for tetracycline resistance in
Enterobacteriaceae isolates obtained from environment, animals and humans. Tet A gene is the most important and prevalent gene among all the resistance genes (Sigirci et al., 2019).

All the phenotypically tetracycline resistant Enterobacteriaceae isolates (154) were subjected to PCR, targeting 577 bp region of tet $A$. Out of 154 phenotypically tetracycline resistant Enterobacteriaceae isolates, 140 samples were found to harbour tet $A$ gene and 14 samples did not possess tet $A$ gene (Table 3 and Fig. 2). Out of 101, 22 and 31 E.coli, Klebsiella and Salmonella tested, 91 (90.09\%), 20 (90.09\%) and 29 (93.54\%) were found to possess tet $A$ gene respectively. 90.9\% positive isolates harboured tet- $A$ gene. Tetracycline resistance of avian pathogens has been reported by several workers (Kolar et al., 2002; Omoya and Ajayi, 2016; Ayandiran et al., 2018). In a similar study conducted by Obeng et al., (2012), 32.6\% (63/193) of the E.coli isolates from free range chicken in Australia were phenotypically tetracycline resistant. But tet A was detected in only $76 \%$ $(48 / 63)$ of the tetracycline resistant isolates. Al Bahry et al., (2013) isolated 46 E.coli from Oman and screened for tetracycline resistance. About 85 and $80 \%$ of the samples possessed tet $A$ and tet $B$ genes respectively.

In the present study, PCR was standardized targeting $800 \mathrm{bp}$ of $b l a_{\mathrm{TEM}}$ gene. Out of 127 samples which were phenotypically resistant to ampicillin, $b l a_{\text {TEM }}$ could be detected in 115 (90.55\%) samples (Table 3 and Fig. 3). 12 samples which were phenotypically resistant to ampicillin didn't show the presence of bla $_{\mathrm{TEM}}$ gene. Out of 93, 18 and 16 E.coli, Klebsiella and Salmonella tested, 85 (91.39\%), $14(77.77 \%)$ and $16(100 \%)$ were found possess bla $a_{\mathrm{TEM}}$ gene respectively. Around $90.55 \%$ of phenotypically positive isolates harboured $b l a_{\text {TEM }}$ gene. 
Table.1 Phenotypic antimicrobial resistance in gut microbiota of desi chicken

\begin{tabular}{|l|l|l|l|}
\hline S.No & \multicolumn{1}{|c|}{ Name of antibiotic } & $\begin{array}{l}\text { No. of samples } \\
\text { tested }\end{array}$ & $\begin{array}{l}\text { No. Resistant } \\
(\%)\end{array}$ \\
\hline 1. & Bacitracin & 217 & $217(100)$ \\
\hline 2. & Colistin & 217 & $217(100)$ \\
\hline 3. & Furazolidone & 217 & $217(100)$ \\
\hline 4. & Nitrofurazone & 217 & $217(100)$ \\
\hline $\mathbf{5 .}$ & Vancomycin & 217 & $217(100)$ \\
\hline 6. & Virginomycin & 217 & $217(100)$ \\
\hline 7. & Tylosine & 217 & $217(100)$ \\
\hline 8. & Doxycycline Hcl & 217 & $154(70.96)$ \\
\hline 9. & Ampicillin & 217 & $127(58.52)$ \\
\hline $\mathbf{1 0 .}$ & Cefotaxime & 217 & $58(26.72)$ \\
\hline $\mathbf{1 1 .}$ & Ciprofloxacin & 217 & $67(30.8)$ \\
\hline 12. & Chloramphenicol & 217 & $49(22.5)$ \\
\hline 13. & Enrofloxacin & 217 & $38(17.5)$ \\
\hline 14. & Gentamicin & 217 & $35(16.1)$ \\
\hline & & & \\
\hline
\end{tabular}

Table.2 Antimicrobial resistance in E.coli, Salmonella spp. and Klebsiella spp.

\begin{tabular}{|l|c|c|c|c|c|c|}
\hline & \multicolumn{2}{|c|}{ E.coli } & \multicolumn{2}{c|}{ Salmonella spp. } & \multicolumn{2}{c|}{ Klebsiella spp. } \\
\hline $\begin{array}{l}\text { Name of } \\
\text { antibiotic }\end{array}$ & $\begin{array}{c}\text { No. of } \\
\text { samples } \\
\text { tested }\end{array}$ & $\begin{array}{c}\text { No. } \\
\text { Resistant } \\
(\%)\end{array}$ & $\begin{array}{c}\text { No. of } \\
\text { samples } \\
\text { tested }\end{array}$ & $\begin{array}{c}\text { No. } \\
\text { Resistant } \\
(\%)\end{array}$ & $\begin{array}{c}\text { No. of } \\
\text { samples } \\
\text { tested }\end{array}$ & $\begin{array}{c}\text { No. } \\
\text { Resistant } \\
(\%)\end{array}$ \\
\hline Bacitracin & 130 & $130(100)$ & 42 & $42(100)$ & 45 & $45(100)$ \\
\hline Colistin & 130 & $130(100)$ & 42 & $42(100)$ & 45 & $45(100)$ \\
\hline Furazolidone & 130 & $130(100)$ & 42 & $42(100)$ & 45 & $45(100)$ \\
\hline Nitrofurazone & 130 & $130(100)$ & 42 & $42(100)$ & 45 & $45(100)$ \\
\hline Vancomycin & 130 & $130(100)$ & 42 & $42(100)$ & 45 & $45(100)$ \\
\hline Virginomycin & 130 & $130(100)$ & 42 & $42(100)$ & 45 & $45(100)$ \\
\hline Tylosine & 130 & $130(100)$ & 42 & $42(100)$ & 45 & $45(100)$ \\
\hline Doxycycline Hcl & 130 & $101(77.69)$ & 42 & $31(73.80)$ & 45 & $22(48.8)$ \\
\hline Ampicillin & 130 & $93(71.53)$ & 42 & $16(38.09)$ & 45 & $18(40)$ \\
\hline Ciprofloxacin & 130 & $38(29.23)$ & 42 & $15(35.71)$ & 45 & $14(31.1)$ \\
\hline Chloramphenicol & 130 & $25(19.23)$ & 42 & $12(28.57)$ & 45 & $12(26.6)$ \\
\hline Cefotaxime & 130 & $20(15.38)$ & 42 & $15(35.71)$ & 45 & $18(40)$ \\
\hline Gentamicin & 130 & $14(10.76)$ & 42 & $7(16.6)$ & 45 & $11(24.4)$ \\
\hline Enrofloxacin & 130 & $20(15.38)$ & 42 & $10(23.80)$ & 45 & $12(26.6)$ \\
\hline
\end{tabular}


Table.3 Genotypic resistance to tetracycline (tet $A$ gene) and ampicillin (bla $a_{\mathrm{TEM}}$ gene) in enteric bacteria of free range chicken

\begin{tabular}{|l|c|c|c|c|}
\hline Gut microbiota & $\begin{array}{c}\text { No. of samples } \\
\text { tested }\end{array}$ & $\begin{array}{c}\text { Resistance to } \\
\text { tet } \boldsymbol{A}(\boldsymbol{\%})\end{array}$ & $\begin{array}{c}\text { No. of samples } \\
\text { tested }\end{array}$ & $\begin{array}{c}\text { Resistance to } \\
\text { bla }_{\text {TEM }}(\boldsymbol{\%})\end{array}$ \\
\hline E.coli & 101 & $91(90.09)$ & 93 & $85(91.39)$ \\
\hline Salmonella spp. & 31 & $29(93.54)$ & 16 & $16(100)$ \\
\hline Klebsiella spp. & 22 & $20(90.09)$ & 18 & $14(77.77)$ \\
\hline
\end{tabular}

Fig.1 Antibiotic resistance in desi chicken of enteric bacteria

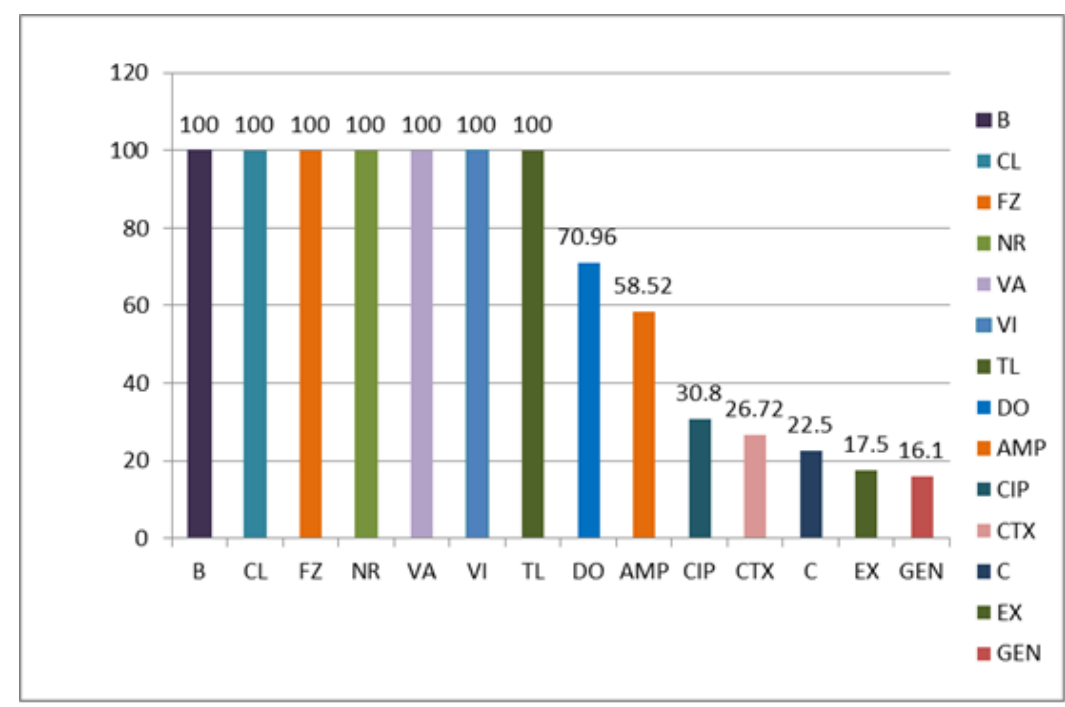

Fig.2 Detection of tet $A$ gene in Enterobacteriaceae of desi chicken

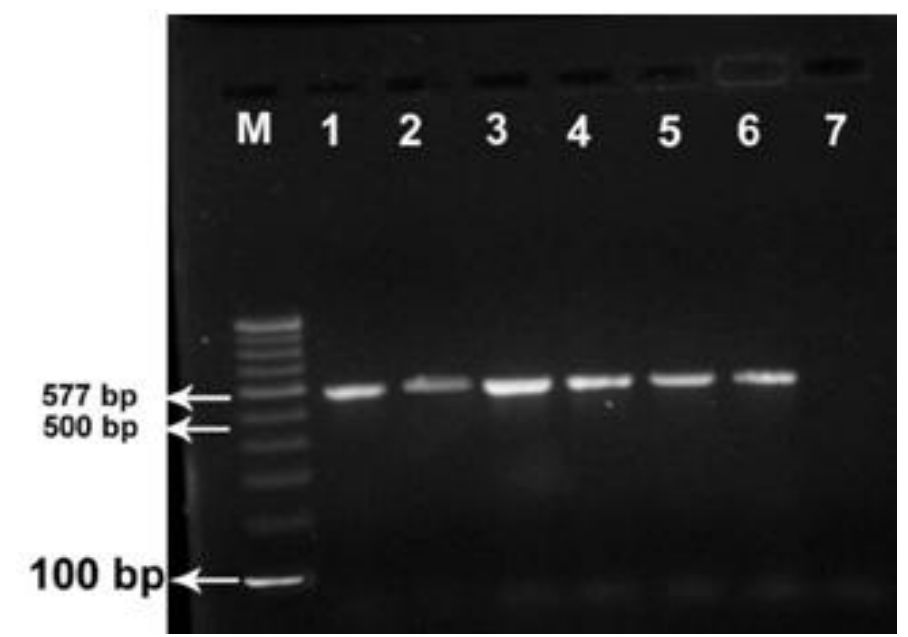

Lane M Molecular weight marker (100bp)

Lane $1 \quad$ Positive control for tet $A$ gene (577bp)

Lane 2 to 6 Desi chicken microbiota carrying tet $A$ gene and

Lane 7 Negative control 
Fig.3 Detection of bla-TEM gene in Enterobacteriaceae of Desi chicken

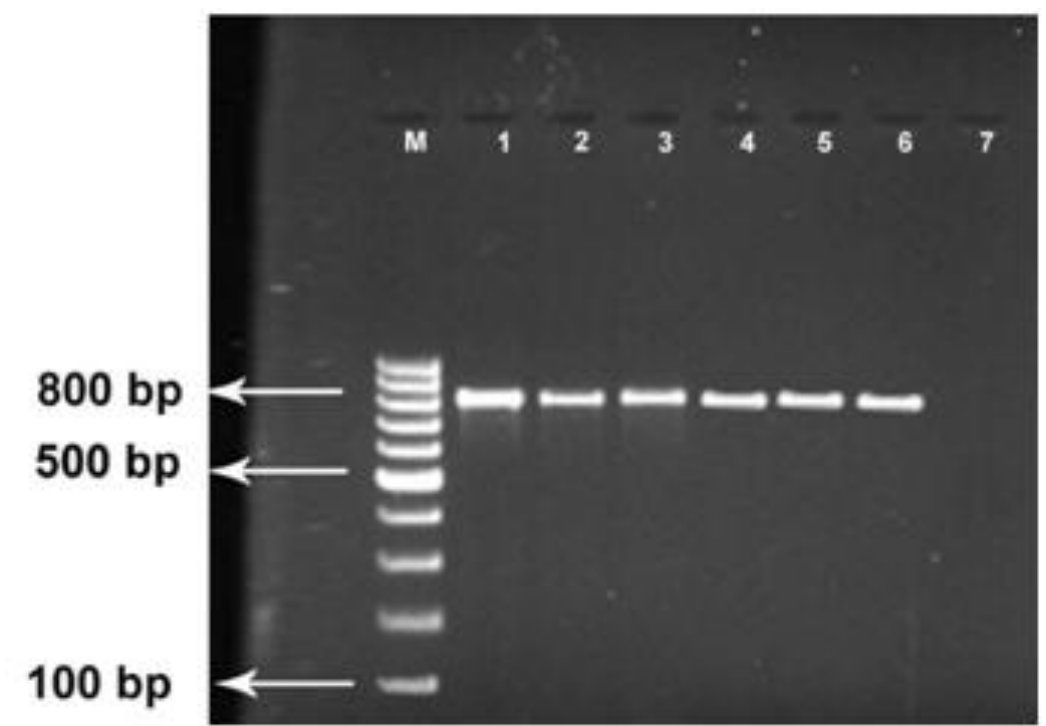

Lane M : Molecular weight marker (100bp)

Lane 1 : Positive control for bla-TEM gene (800bp)

Lane 2 to 6: Desi chicken microbiota carrying bla-TEM gene

Lane 7 : Negative control

Similar findings of ampicillin resistance were reported in chicken worldwide (Kar et al., 2015; Chishimba et al., 2016 and Sailu et al., 2017). Younis et al., (2017) from Egypt reported $78 \%$ resistance to ampicillin among the E.coli isolates of poultry origin by PCR targeting $b l a_{\text {TEM }}$ gene. In a study conducted by Langata et al., (2019) in Nairobi, $43 \%$ of phenotypically ampicillin resistant E.coli isolates were positive for $b l a_{\mathrm{TEM}}$ gene in PCR.

In conclusion, the results of the present study revealed the phenotypic and genotypic antibiotic resistance in the enteric microbiota of desi chicken. Though antibiotics are not being used in the rearing of desi chicken, they might have acquired the resistant bacteria from the environment and may spread these bacteria to other animals and humans. Enteric bacteria especially, the organisms belonging to family Enterobacteriaceae serve as the indicator organisms for assessing the antimicrobial resistance.

\section{References}

Al-Bahry, S, N., Al-Mashani, B., M, AlAnsari, A S., Elshafie, A, E and Mahmoud I, Y, 2013. Escherichia coli tetracycline efflux determinants in relation to tetracycline residues in chicken. Asian Pac. J. Trop .Med. 6 (9): 718-722.

Ayandiran, T, O., Falgenhauer, L., Schmiedel, J., Chakraborty, $\mathrm{T}$ and Ayeni, F, A, 2018. High resistance to tetracycline and ciprofloxacin in bacteria isolated from poultry farms in Ibadan, Nigeria. J. I. Infect. Dev. Ctries. 12 (06): 462-470.

Bauer, A.W., Kirby, W, M., Sherris, J.C and Truck, M, 1966. Antibiotic susceptibility testing by a standardized single disk method. A. J. C. P. 45 (4): 493-496.

Chishimba, K., Hang,Ombe, B, M., Muzandu, K., Mshana, S, E., Matee, M, I., Nakajima, C and Suzuki, Y, 2016. 
Detection of extended-spectrum betalactamase-producing Escherichia coli in market-ready chickens in Zambia. Int. J. Microbiol.

CLSI, 2014. Clinical Laboratory Standards Institute, Performance Standards For Antimicrobial Susceptibility Testing. Twenty-Fourth Informational Supplement M 100-S24, Wayne, PA, USA.

Dallenne, C., Da Costa, A., Decré, D., Favier, $\mathrm{C}$ and Arlet, G, 2010. Development of a set of multiplex PCR assays for the detection of genes encoding important $\beta$-lactamases in Enterobacteriaceae. $J$. Antimicrob. Chemother. 65 (3): 490495.

Ghoddusi,A., Fasaei, B, N., Karimi, V., Tamai, I, A., Moulana, Z and Salehi, T, $Z$, 2015. Molecular identification of Salmonella infantis isolated from backyard chickens and detection of their resistance genes by PCR. I.J.V.R, 16(3): 293.

Hamisi, Z., Tuntufye, $\mathrm{H}$ and Shahada, F, 2014. Antimicrobial resistance phenotypes of Escherichia coli isolated from tropical free range chickens. Int. J. Sci. Res, 3 (9): 34-37.

Hayati, M., Indrawati, A., Mayasari, N, L P, I., Istiyaningsih, I and Atikah, N, 2019. Molecular detection of extendedspectrum $\quad \beta$-lactamase-producing Klebsiella pneumoniae isolates of chicken origin from East Java, Indonesia. Vet. World. 12 (4): 578-583.

Kar, D., Bandyopadhyay, S., Bhattacharyya, D., Samanta, I., Mahanti, A., Nanda, P, K., Mondal, B., Dandapat, P., Das, A, K., Dutta, T, K and Bandyopadhyay, S, 2015. Molecular and phylogenetic characterization of multidrug resistant extended spectrum beta-lactamase producing Escherichia coli isolated from poultry and cattle in Odisha, India. Infect Genet Evol. 29: 82-90.
Kolar, M., Pantucek, R., Bardon, J., Vagnerova, I., Typovska, H., Valka, I and Doskar, J, 2002. Occurrence of antibiotic-resistant bacterial strains isolated in poultry. Vet Med Czech. 47: 52-59.

Langata, L, M., Maingi, J, M., Musonye, H, A., Kiiru, J and Nyamache, A, K, 2019 Antimicrobial resistance genes in Salmonella and Escherichia coli isolates from chicken droppings in Nairobi, Kenya. BMC Res. Notes. 12 (1): 22.

Obeng, A, S., Rickard, H., Ndi, O., Sexton, M., and Barton, M, 2012 Antibiotic resistance, phylogenetic grouping and virulence potential of Escherichia coli isolated from the faeces of intensively farmed and free range poultry. Vet.Microbiol, 154(3-4): 305-315.

Odomene, I, F, and Enwere, O, O, 2018. Suceptibility pattern to common antibiotics of intestinal Escherichia coli from slaughtered commercially grown chickens. I. J. C. M. R. 5(3): 25-30.

Ojo, O, E., Ogunyinka, O, G., Agbaje, M., Okuboye, J, O., Kehinde, O, O and Oyekunle, M, A, 2012.Antibiogram of Enterobacteriaceae isolated from freerange chickens in Abeokuta, Nigeria. Veterinarskiarhiv. 82 (6): 577-589.

Omoya, F, O, and Ajayi, K, O, 2016. Antibiotic resistance pattern of pathogenic bacteria isolated from poultry droopings in akure, Nigeria. FUTA Journal of Research in Sciences. 12 (2): $1-9$.

Randall L P, Cooles S W, Osborn M K, Piddock L J V and Woodward M J 2004 Antibiotic resistance genes, integrons and multiple antibiotic resistance in thirty-five serotypes of Salmonella enterica isolated from humans and animals in the UK. J. Antimicrob. Chemother. 53(2): 208-216.

Rao, T, S, 2009. Studies on detection of Shiga toxin producing Escherichia coli 
in meat and meat products by multiplex polymerized reaction and their public health significance. Ph.D. Thesis submitted to Gadvasu, Ludhiana141004.

Samanta, I., Joardar, S, N., Das, P, K., Sar, T, K., Bandyopadhyay, S., Dutta, T, K, and Sarkar, U, 2014. Prevalence and antibiotic resistance profiles of Salmonella serotypes isolated from backyard poultry flocks in West Bengal, India. J. Appl.Poult. Res. 23 (3): 536545.

Sailu, E, M., Vahjen, W, and Zentek, J, 2017. Types and prevalence of extended spectrum beta lactamase producing Enterobacteriaceae in poultry. Anim. Health. Res. Rev. 18 (1): 46-57.

Sigirci, B, D., Celik, B., Kahraman, B, B., Bagcigil, A, F, and Ak, S, 2019. Tetracycline resistance of Enterobacteriaceae isolated from feces of synanthropic Birds. J.Exot. Pet Med. 28: 13-18.

Younis, G., Award, A, and Mohamed, N, 2017. Phenotypic and genotypic characterization of antimicrobial susceptibility of avian pathogenic $E$. coli isolated from broiler chickens. Vet. World. 10 (10): 1167-1172.

\section{How to cite this article:}

Divya, M., B. Sreedevi, R. K. Chaitanya and Srilatha, Ch. 2019. Phenotypic and Genotypic Characterization of Antimicrobial Resistance of Enterobacteriaceae Isolated from Free Range Chicken in Andhra Pradesh. Int.J.Curr.Microbiol.App.Sci. 8(12): 2568-2576. doi: https://doi.org/10.20546/ijcmas.2019.812.300 